\title{
Parasites of pigeons (Columba livia) in urban areas of lages, Southern Brazil
}

\author{
SANDRA MÁRCIA TIETZ MARQUES*, ROSILÉIA MARINHO DE QUADROS**, \\ CÍNTIA JARDIM DA SILVA** and MARISA BALDO**
}

\begin{abstract}
The prevalence of ectoparasites and endoparasites was studied in 58 free-living pigeons (Columba livia) in urban areas of Lages, in the state of Santa Catarina, Brazil. The pigeons were visually inspected and fecal and blood samples were collected to determine the presence of ectoparasites. The serological diagnosis was established through the use of blood smears stained with Quick Panoptic and Giemsa methods. The fecal samples were analyzed using Sheather's method. The Quick Panoptic and Giemsa methods detected 67.24\% (39/58) and 46.55\% (27/58) of Haemoproteus sp, respectively. The prevalence rate amounted to $57 \%$ of 116 smears analyzed ( $P$ value $=0.0387$; odds ratio $=2.357$ with a 95\% confidence interval). The prevalence of gastrointestinal parasites was $74.14 \%$ (43/58). Protozoa (100\% for Eimeria sp.) were detected in $86.05 \%$ of the cases and nematodes (Ascaridia sp. and Capillaria sp.) in 32.56\%, whereas $20.93 \%$ of the pigeons were infected by multiple parasites. The fly Pseudolynchia canariensis was found beneath the feathers of all pigeons. This is the first report of parasites in $\boldsymbol{C}$. livia in the state of Santa Catarina.
\end{abstract}

Key words: pigeons, Columba livia, Hippoboscidae, helminths, protozoa.

\section{INTRODUCTION}

Pigeons of the order Columbiformes are ubiquitous birds and can be found in virtually every town and city around the globe. Columba livia is a species that descends from wild rock pigeons, which live in Mediterranean Europe. There has been a sharp increase in the number of these birds in Brazilian cities, drawing the attention of authorities to health and building defacement issues ${ }^{1}$.

Those who watch these birds can barely imagine how detrimental their disorderly reproduction may be and how many risks they pose to human health. They constitute a major source of infection and transmission of diseases. They are often a cause for repulsion and nuisance due to the accumulation of fecal droppings and to the disruptive noise associated with their presence. Humans are infected by inhaling fecal dust from cages or from sites that have been contaminated with dry feces, urine and other droppings. This usually occurs among breeders, veterinary doctors, industrial workers, and cleaning workers ${ }^{2}$.

Several health problems can affect pigeons, but parasite infections play a major role. The prevalence of $C$. livia parasites was studied on

* Laboratory of Protozoology, Department of Clinical Veterinary Pathology, School of Veterinary Sciences of Universidade Federal do Rio Grande do Sul (UFRGS), Porto Alegre, Rio Grande do Sul, Brazil.

** Department of Biological and Health Sciences, School of Biology of Universidade do Planalto Catarinense (UNIPLAC), Lages, Santa Catarina, Brazil. 
the Canary Islands, where Pseudolynchia (P.) canariensis was observed in 36\%, Haemoproteus (H.) columbae in $82 \%$, coccidial oocysts in $50 \%$ and Ascaridia columbae in $40 \%$ of the pigeons. ${ }^{3}$ In Costa Rica, Haemoproteus sp was detected in $4.8 \%$ of birds $^{4}$; in Queensland, Australia, a total of 3,059 birds were examined and Haemoproteus sp was found in $31.4 \%$ of them ${ }^{5}$.

Endemic free-ranging Galapagos doves (Zenaida galapagoensis) and rock pigeons (C. livia) were surveyed in several islands of the Galapagos archipelago to establish the sample prevalence of blood parasites. Haemoproteus sp, the only blood parasite identified, was found in $89 \%$ of the Galapagos doves sampled, but not in the rock doves. ${ }^{6}$ In Bulgaria, the total prevalence of the genus Haemoproteus amounted to $18.5 \%{ }^{7}$. In Alaska, a study for the detection of blood parasites in birds during the breeding season revealed that the prevalence of Haemoproteus ranged from 5 to $18 \%{ }^{8}$.

The prevalence of blood parasites was investigated in Japanese wild birds (from 1988 to 2001) and $5.1 \%$ were infected with Haemoproteus sp ${ }^{9}$. A total of 315 birds from Villavicencio and San Miguel, Colombia, were tested for the presence of hematozoa; of these, 50 birds $(15.9 \%)$ harbored blood parasites of the genus Haemoproteus. ${ }^{10}$ Haemaproteus was the most prevalent parasite among C. livia in Uganda $(76.5 \%)^{11}$, in South Africa $(80 \%)^{12}$ and in the USA $(22.8 \%)^{13}$.

In the state of Minas Gerais, in southeastern Brazil, a research study with free-living pigeons (C. livia domestica) showed that all pigeons were infested with $P$. canariensis - a bloodfeeding louse fly - and with $H$. columbae and Eimeria sp. oocysts. A. columbae was detected in $4.91 \%$ of the pigeons and $3.27 \%$ presented with mixed infections caused by $A$. columbae and Raillietina $\mathrm{spp}^{14}$. The prevalence and intensity of blood parasites in three species of wild doves were studied in the western region of the state of São Paulo, Brazil. H. columbae was found in the blood of all dove species ${ }^{15,16}$.

Hippoboscidae flies are ubiquitous and a vector for Haemoproteus sp among pigeons and doves of the order Columbiformes, whereas $P$. canariensis is the vector of $H$. columbae among Columba livia pigeons, both in the case of natural and experimental infections ${ }^{11,17}$. They can be found in all biogeographical regions and usually infect birds and some mammalian orders. Currently, there are 30 species in Brazil, classified into 10 genera; however, there is a paucity of information on their distribution and on their hosts in all Brazilian regions ${ }^{14-17}$. Gastrointestinal parasites are underinvestigated in birds. A report on captive wild birds, including those of the Columbidae family, carried out at a scientific rearing station and in a park in the city of Recife, northeastern Brazil, showed that $29.9 \%$ of the birds tested positive for helminths and/or protozoa; also showing that Capillaria sp was the most prevalent parasite, in addition to confirming the presence of Ascaridia sp and coccidial oocysts $(8.3 \%)^{18}$.

The aim of this study was to determine the presence of ectoparasites and endoparasites in free-living $C$. livia)that congregate around the public squares of Lages.

\section{MATERIALAND METHODS}

The pigeons included in this study were surveyed on the streets and squares of Lages, state of Santa Catarina, southern Brazil. They were captured with a fine mesh net after authorization by the Municipal Department of Environmental Protection and by the State Military Police Department of Santa Catarina. The study was approved by the Research Ethics Committee of Universidade do Planalto Catarinense (UNIPLAC). The pigeons were tagged with a leg ring to avoid multiple sampling.

A total of 58 male and female, different-aged pigeons were captured with a fine mesh net at different times between April and August 2004. Blood samples were initially collected from the pigeons. Thereafter, the pigeons were caged and taken to the Animal Facility of UNIPLAC, where they received water ad libitum until their stools could be sampled. After that, the pigeons were visually inspected for the detection, collection and identification of ectoparasites, and set loose immediately after that. Ectoparasites were identified using a stereo microscope and taxonomic keys ${ }^{17}$.

The blood samples were collected using an insulin syringe inserted through a brachial vein catheter. Each sample provided two blood smears, fixed with methanol and stained with Quick Panoptic and Giemsa dyes ${ }^{19}$. The slides were analyzed under light microscopy using an oil 
immersion objective.

The fecal matter was analyzed by Sheather's method, whereby protozoa and helminths were detected and identified, with decantation of the supernatant extract on the glass slide after the centrifugation flotation technique ${ }^{20}$.

Fisher's exact test (Graphpad Software, version 2.04) was used to compare the two diagnostic methods. An alpha error of less than $5 \%(\mathrm{p}<0.05)$ was considered statistically significant.

\section{RESULTS}

The fly Pseudolynchia canariensis was found beneath the feathers of all pigeons (Figure 1).

Haemoproteus $\mathrm{sp}$, a protozoan transmitted by biting dipterans of the Hippoboscidae family, was the major parasite detected. The serological diagnosis through the use of staining methods revealed that $67.24 \%(39 / 58)$ of the samples yielded positive results when stained with the Quick Panoptic dye. Among the 58 slides stained with Giemsa, 46.55\% (27/58) demonstrated the presence of Haemoproteus sp (Figure 2).

The positive and negative results for 116 blood smears are shown in Table 1.

The statistical analysis demonstrated that a two-sided $\mathrm{P}$ value of 0.0387 was considered to be significant, with an odds ratio of 2.357 and a 95\% confidence interval. This difference showed that the Quick Panoptic method was more sensitive in detecting parasites in blood smears of Columba livia.

The overall prevalence of gastrointestinal parasites amounted to $74.14 \%(43 / 58)$, with $86.05 \%$ (37/43) for protozoa, with the detection of Eimeria sp oocysts in all positive samples. Of these samples, $27.9 \%(12 / 43)$ were infected by multiple parasites, showing associations between Eimeria sp. and Ascaridia sp and Ascaridia sp and Capillaria sp, whereas these three parasites were detected in $11.62 \%(5)$ of the samples. The prevalence of nematodes was $32.56 \%(14 / 43)$, and parasites of the genus Ascaridia (13/14) $(92.85 \%)$ prevailed over those of the genus Capillaria (3/14) (21.42\%) (Figure 3). The highest infection rate was that of Eimeria oocysts.

\section{DISCUSSION}

The result for $P$. canariensis is the same observed for pigeons of the same species in the state of Minas Gerais, southeastern Brazil. ${ }^{14}$ The study conducted in São Paulo, also in southeastern Brazil, with three pigeon species, showed smaller prevalence rates of $58.4 \%$, $36.5 \%$ and $33.6 \%$, respectively ${ }^{16}$. On the Canary Islands, the prevalence of the fly $P$. canariensis amounted to $36 \%{ }^{3}$.

The results of the present study demonstrated higher rates of blood parasites than the other few studies carried out in Brazil in two regions of the state of São Paulo for H. columbae,

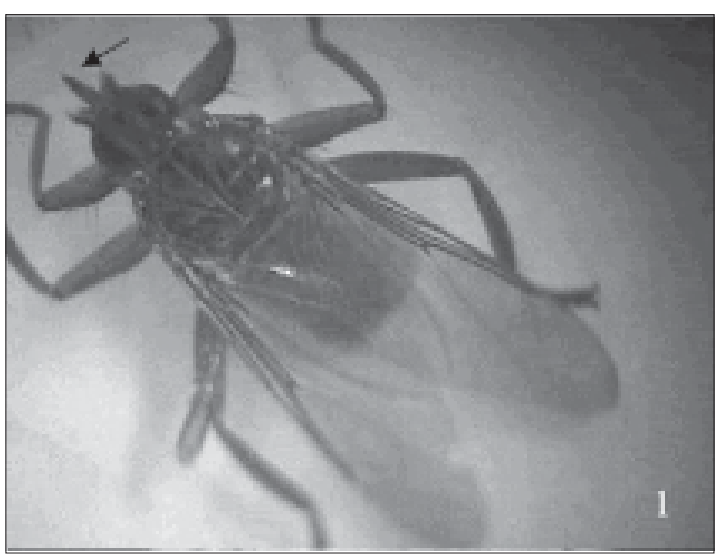

Figure 1. Hippoboscidae fly detected in Columba livia pigeons in Lages, state of Santa Catarina, Brazil.

Table 1. Diagnosis of Haemoproteus sp in Columba livia pigeons using the Quick Panoptic and Giemsa staining methods

\begin{tabular}{lccr}
\hline Haemoproteus sp & Quick Panoptic & Giemsa & \multicolumn{1}{c}{ Total } \\
\hline Positive & $39(34 \%)$ & $27(23 \%)$ & $66(57 \%)$ \\
Negative & $19(16 \%)$ & $31(27 \%)$ & $50(43 \%)$ \\
Total & $58(50 \%)$ & $58(50 \%)$ & $116(100 \%)$ \\
\hline
\end{tabular}

$\mathrm{p}(<0.05 \%)$ 


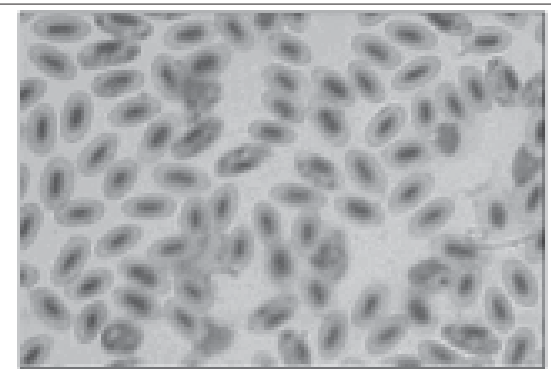

(Quick Panoptic)

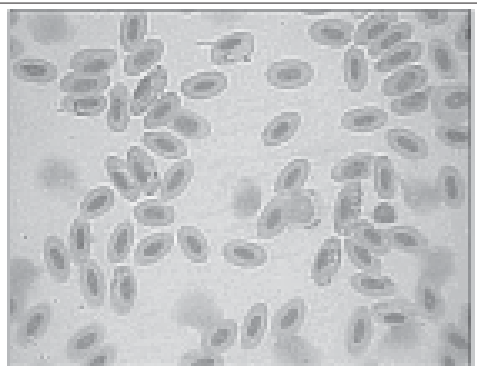

(Giemsa)

Figure 2. Blood smears of Columba livia pigeons infected by Haemoproteus sp and submitted to the Quick Panoptic and Giemsa staining methods (100 X).

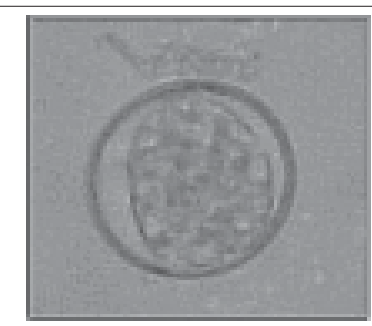

Eimserion sp, (a)

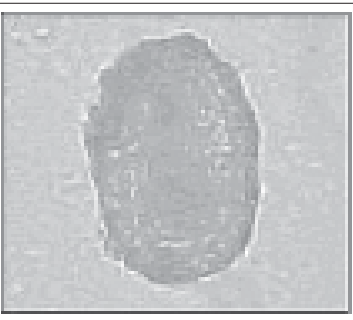

Ascruidia sp. (b)

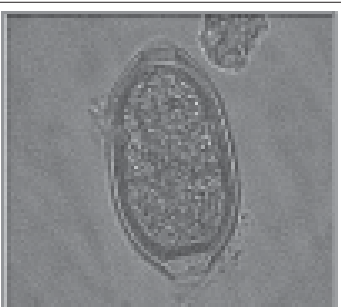

Copillaria sp. (c)

Figure 3. Eimeria oocyst (a), Ascaridia egg (b) and Capillaria sp. (c). (40 X).

however, with a smaller rate than was observed in Minas Gerais (100\% for $H$. columbae). The investigation into the prevalence of blood parasites in pigeons and other birds in Costa Rica ${ }^{4}$, Alaska, ${ }^{8}$ and $\mathrm{Japan}^{9}$ revealed rates lower than $10 \%$; in the United States $^{13}$, Colombia ${ }^{10}$, Bulgaria ${ }^{7}$ and in Queensland $^{5}$, Australia, the prevalence rates ranged from 20 to $32 \%$ for Haemoproteus sp. Similar or higher prevalence rates for Haemoproteus sp than those observed in this study were found in Uganda ${ }^{11}(76.5 \%)$, in South Africa $^{12}(80 \%)$, on the Canary Islands ${ }^{3}(82 \%)$, and on the Galapagos archipelago ${ }^{6}(89 \%)$. The prevalence of gastrointestinal nematodes in Columba livia pigeons was higher than that obtained for Minas Gerais, in southeastern Brazil14; another study showed coccidial oocysts, but no prevalence data, unlike another study with pigeons from the public squares of Lages, where $100 \%$ of fecal samples revealed the presence of oocysts, in addition to a prevalence rate higher than $30 \%$ for nematode eggs, besides the predominance of Ascaridia $\mathrm{sp}^{3,14,18}$. Neither of the referenced studies revealed the presence of ectoparasites or endoparasites that could be zoonotic to humans, nor did the present study.

This is the first report on ectoparasites and endoparasites in Columba livia in public squares of Lages, in the state of Santa Catarina, Brazil.

\section{RESUMO}

A prevalência de ecto e endoparasitos de 58 pombos (Columba livia) de vida livre foi estudada em áreas urbanas de Lages, estado de Santa Catarina, Brasil. Os pombos foram submetidos ao exame visual para a coleta e identificação de ectoparasitos, coletas de fezes e sangue. O diagnóstico hemoparasitológico foi através de esfregaços sangüíneos corados pelas técnicas de Panótico Rápido e Giemsa. As fezes foram processadas pelo método de Sheather. Entre os hemoparasitos destacou-se o Haemoproteus sp., com $67,24 \%(39 / 58)$ para a técnica de Panótico Rápido e 46,55\% (27/58) para a técnica de Giemsa. Dos 116 esfregaços analisados, a prevalência foi de $57 \%(\mathrm{P}=0,0387$; Odds Ratio $=2,357$ e Intervalo de Confiança de 95\%). A 
prevalência de parasitos gastrintestinais foi de $74,14 \%$ (43/58) com $86,05 \%$ para protozoários ( $100 \%$ para Eimeria sp.), $32,56 \%$ para nematódeos (Ascaridia sp. e Capillaria sp.) e $20,93 \%$ multiparasitados. A presença da mosca Pseudolynchia canarienses foi observada entre as penas de todas as aves. Este é o primeiro registro destes parasitos em C. livia no estado de Santa Catarina.

\section{REFERENCES}

1.- PONTES TC. Os Homens e os Pombos nos Centros Urbanos. Available at http:www.pragasurbanas/ pombos.htm, accessed on July 27, 2006.

2.- SILVEIRA T L. Pombos: símbolos da paz ou ameaça à saúde pública? Available at http://www.geocities.com/ RainFoest/Jungle/9625/numerotreze4.htm, accessed on March 12, 2006.

3.- FORONDA P, VALLADARES B, RIVERA-MEDINA JA, et al. Parasites of Columba livia (Aves : Columbiformes) in Tenerife (Canary Islands) and their role In the conservation biology of the Laurel pigeons. Parasitology 2004; 1: 311-6.

4.- VALKIUNAS G, IEZHOVA TA, BROOKS DR, et al. Additional observations on blood parasites of birds in Costa Rica. J Wildl Dis 2004; 40: 555-61.

5.- ADLARD R D, PEIRCE MA, LEDERER R. Blood parasites of birds from southeast Queensland. Ornithology 2004; 104: 191-6.

6.- PADILLA LR, SANTIAGO-ALARCON D, MERKEL J, et al. Survey for Haemoproteus spp., Trichomonas gallinae, Chlamydophila psittaci, and Salmonella spp. in Galapagos Islands columbiformes. J Zoo Wildl Med 2004; 35: 60-4.

7.- SHURULINKOV P, GOLEMANSKY V. Haemoproteids (Haemosporida: Haemoproteidae) of wild birds in Bulgaria. Acta Protozool 2002; 41: 359-74.

8.- DEVICHE P, GREINER E C, MANTECA X. Interspecific variability of prevalence in blood parasites of adult passerine birds during the breeding season in
Alaska. J Wildl Dis 2001; 37: 28-35.

9.- MURATA K. Prevalence of blood parasites in Japanese wild birds. J Vet Med Sci 2002; 64: 785-90.

10.- RODRIGUEZ O A, MATTA N E. Blood parasites in some birds from eastern plains of Colombia. Mem Inst Oswaldo Cruz 2001; 96: 1173-6.

11.- DRANZOA C, OCAIDO M, KATETE P. The ecto, gastrointestinal and haemoparasites of live pigeons (Columba livia) in Kampala, Uganda. Avian Pathol 1999; 28: 119-24.

12.- MUSHI EZ, BINTA M G, CHABO R G, et al. Parasites of domestic pigeons (Columba livia domestica) in Sebele, Gaborone, Botswana. J S Afr Vet Assoc 2000; 71: 249-50.

13.- GARVIN M C, REMSEN J V, BISHOP M A, et al. Hematozoa from passeriform birds in Louisiana. $J$ Parasitol 1993; 79: 318-21.

14.- OLIVEIRA P R, MUNDIM M J S, CABRAL D D, et al. Levantamento da Fauna Parasitária das Pombas Domésticas (Columba livia domestica) de Uberlândia, MG, Brasil. Vet Not 2000; 6: 53-56 Available at http:/ /www.famev.ufu.br/vetnot/vetnot6/res6-2-7.html, accessed on April 13, 2006.

15.- ADRIANO E, CORDEIRO N. Prevalence and Intensity of Haemoproteus columbae in Three Species of Wild Doves from Brazil. Rio de Janeiro. Mem Inst Oswaldo Cruz 2001; 96: 175-8.

16.- DIAS R M D S, CHIEFFI P P, TOLEZANO J E, et al. Hemoparasitas de aves capturadas em duas regiões do Estado de São Paulo, Brasil. Rev Inst Adolfo Lutz 1984; 44: 41-6.

17.- GRACIOLLI G, CARVALHO C J B. Hippoboscidae (Diptera, Hippoboscoidea) no Estado do Paraná, Brasil: chaves de identificação, hospedeiros e distribuição geográfica. Rev Bras Zool 2003; 20: 667-74.

18.- FREITAS F L de, OLIVEIRA M B de, OLIVEIRA A B de, et al. Parásitos gastrointestinales de aves silvestres en cativeiro en el estado de Pernambuco, Brasil. Parasitol Latinoam 2002; 57: 50-4

19.- CARLI GA de. Diagnóstico Laboratorial das Parasitoses Humanas - Métodos e Técnicas. Rio de Janeiro: Editora Medsi, 1994.

20.- HOFFMANN R P. Diagnóstico de parasitismo veterinário. Porto Alegre, Sulina, 1987. 150 p.

\section{Correspondencia a:}

Sandra Márcia Tietz Marques

Faculdade de Veterinária. Universidade Federal do Rio Grande do Sul Rua Aneron Correa de Oliveira 74, ap. 201 CEP: 91410-070

Bairro Jardim do Salso, Porto Alegre, RS, Brazil

E-mail: sandra.marques@ufrgs.br Fax:+55 5133087305 